\title{
The role of thyroid hormone calorigenesis in the redox regulation of gene expression
}

\author{
PATRICIA VARELA ${ }^{1}$, GLADYS TAPIA ${ }^{2}$, VIRGINIA FERNÁNDEZ ${ }^{2}$ \\ and LUIS A VIDELA ${ }^{2}$
}

${ }^{1}$ Cellular and Molecular Biology Program and ${ }^{2}$ Molecular and Clinical Pharmacology Program, Institute of Biomedical Sciences, Faculty of Medicine, University of Chile, Santiago, Chile

\begin{abstract}
Thyroid hormone (TH; 3,3,5-triiodothyronine, $\mathrm{T}_{3}$ ) is required for the normal function of most tissues, with major effects on $\mathrm{O}_{2}$ consumption and metabolic rate. These are due to transcriptional activation of respiratory genes through the interaction of $\mathrm{T}_{3}$-liganded $\mathrm{TH}$ receptors with $\mathrm{TH}$ response elements or the activation of intermediate factors, with the consequent higher production of reactive $\mathrm{O}_{2}$ species (ROS) and antioxidant depletion. $\mathrm{T}_{3}$-induced oxidative stress in the liver triggers the redox upregulation of the expression of cytokines (tumor necrosis factor- $\alpha[\mathrm{TNF}-\alpha]$, interleukin-10), enzymes (inducible nitric oxide synthase, manganese superoxide dismutase), and anti-apoptotic proteins (Bcl-2), via a cascade initiated by TNF- $\alpha$ produced by Kupffer cells, involving inhibitor of $\kappa \mathrm{B}$ phosphorylation and nuclear factor- $\kappa \mathrm{B}$ activation. Thus, $\mathrm{TH}$ calorigenesis triggers an expression pattern that may represent an adaptive mechanism to re-establish redox homeostasis and promote cell survival under conditions of ROS toxicity secondary to TH-induced oxidative stress. Mechanisms of expression of respiratory and redox-sensitive genes may be functionally integrated, which could be of importance to understand the complexities of $\mathrm{TH}$ action and the outcome of thyroid gland dysfunction.
\end{abstract}

Key terms: Thyroid hormone; Calorigenesis; Oxidative stress; Gene expression

\section{INTRODUCTION}

Thyroid hormones (TH) are required for the normal function of most tissues of the body, playing essential roles in growth, development, differentiation, and metabolism, with major effects on $\mathrm{O}_{2}$ consumption $\left(\mathrm{QO}_{2}\right)$ and metabolic rate (Videla, 2000). Current available data indicate that TH calorigenesis is achieved by both (i) a short-term nongenomic signaling mechanism mediated by 3,5diiodothyronine and 3,3,5-triiodothyronine $\left(\mathrm{T}_{3}\right)$ leading to the allosteric activation of cytochrome-c oxidase (Moreno et al., 2002), and (ii) a long-term pathway upregulating nuclear and mitochondrial gene transcription through $\mathrm{T}_{3}$ signaling (Fig. 1) (Yen, 2001; Weitzel et al., 2001;
Lanni et al., 2003). In several target organs such as liver, a higher pro-oxidant activity is developed as result of the functional interdependence established between $\mathrm{TH}$ calorigenesis, cellular $\mathrm{QO}_{2}$, and generation of reactive oxygen (ROS) (Fernández et al., 1985; 2003; Fernández \& Videla, 1993a) and nitrogen (RNS) species (Fernández et al., 1997). This respiratory component accounts for $16-25 \%$ of the net increase in total $\mathrm{QO}_{2}$ (Fernández \& Videla, 1993b). $\mathrm{T}_{3^{-}}$ induced free radical activity decreases the cellular antioxidant defenses, leading to oxidative stress (Fernández \& Videla, 1996) in liver and in extrahepatic tissues of experimental animals exhibiting a calorigenic response (Fig. 1), a phenomenon also observed in human hyperthyroidism (Videla, 2000). Recent

Corresponding author: Luis A. Videla, Programa de Farmacología Molecular y Clínica, Instituto de Ciencias Biomédicas, Facultad de Medicina, Universidad de Chile, Casilla 70000, Santiago-7, Chile. Telephone: 56-2-9786256. Fax: 56-2-7372783. E-mail: 1videla@med.uchile.cl 
studies by Fernández et al. (2005a; 2005b) highlighted a novel nongenomic mechanism by which TH achieve the redox regulation of gene expression through activation of redox-sensitive transcription factors, as an adaptive response to re-establish redox homeostasis (Fig. 1).
REGULATION OF GENE TRANSCRIPTION BY THYROID HORMONE

Activation of gene transcription by $\mathrm{T}_{3}$ involves its binding to different thyroid hormone (TH) receptor (TR) isoforms that are ligand-regulatable transcription factors

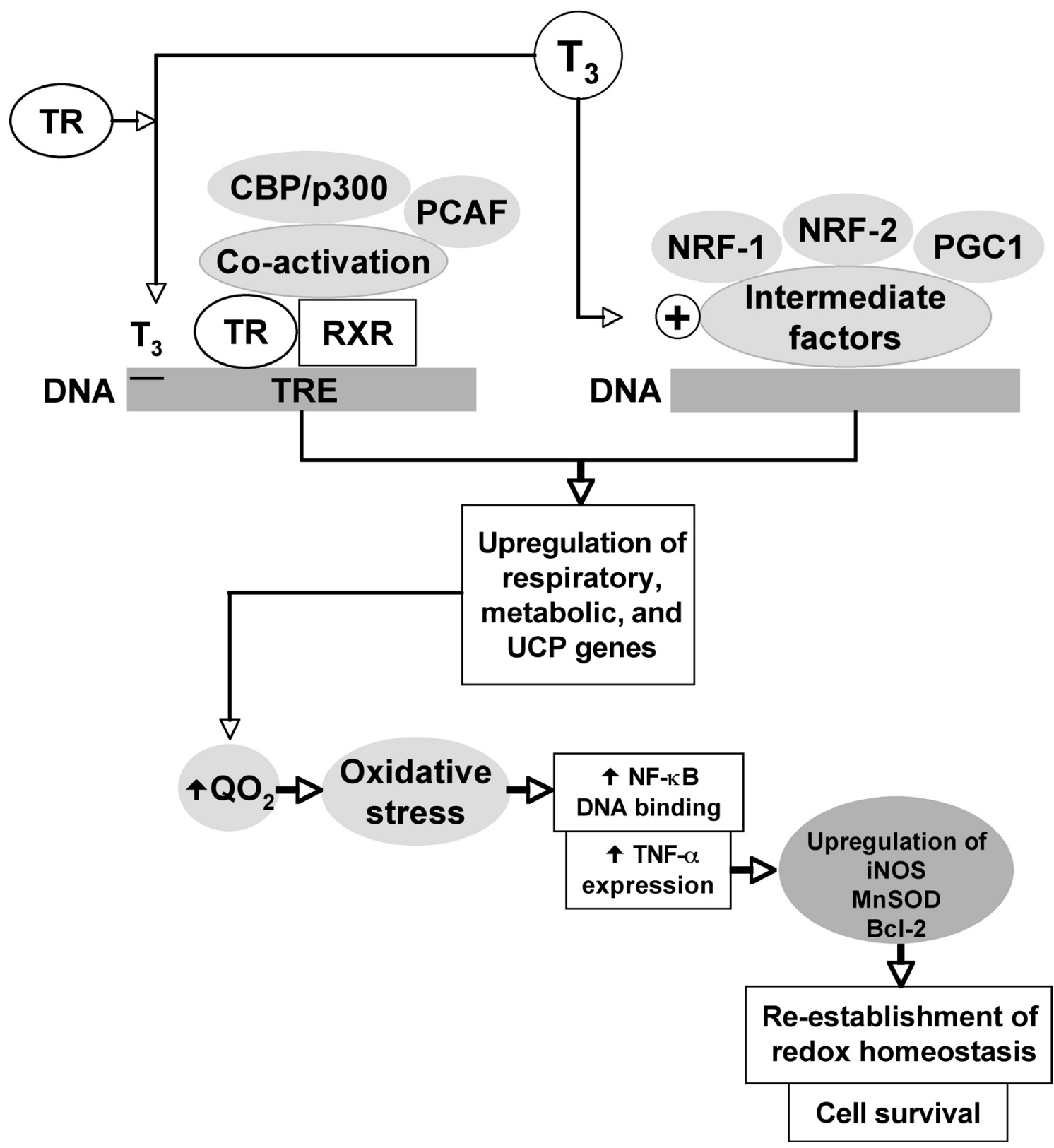

Figure 1: Relationship between transcriptional activation by $\mathrm{T}_{3}, \mathrm{O}_{2}$ metabolism and oxidative stress, and the redox regulation of gene expression. Abbreviations: CBP, CREB binding protein; iNOS, inducible nitric oxide synthase; MnSOD, manganese superoxide dismutase; $\mathrm{NF}-\kappa \mathrm{B}$, nuclear factor- $\mathrm{KB}$; p300, CBP related protein; PCAF, p300/CBP-associated factor; $\mathrm{T}_{3}, \mathrm{~L}-3,3,5-$ triiodothyronine; TNF- $\alpha$, tumor necrosis factor- $\alpha$. 
having a similar domain organization. Liganded TR isoforms can bind to $\mathrm{TH}$ response elements (TRE) in DNA, specially in the form of $\mathrm{TR} /$ retinoic acid receptor (RXR) heterodimers, which can form complexes with specific coactivators, thus regulating histone acetylation and determining gene transcription (Fig. 1). Alternatively, $\mathrm{T}_{3^{-}}$ responsive genes that do not interact with TR may involve an indirect induction mechanism via the activation of intermediate factors, such as nuclear respiratory factor-1 (NRF-1) and NRF-2 or the peroxisome proliferator-activated receptor gamma coactivator 1 (PGC1)(Yen, 2001; Weitzel et al., 2001). These $\mathrm{T}_{3}$-dependent signaling mechanisms induce the synthesis of the enzymes involved in energy metabolism leading to higher rates of $\mathrm{O}_{2}$ consumption $\left(\mathrm{QO}_{2}\right)$, oxidative phosphorylation, and ATP production. The latter process being partially balanced by intrinsic uncoupling afforded through induction of uncoupling proteins (UCP) by $\mathrm{T}_{3}$ (Lanni et al., 2003)(Fig.1). $\mathrm{T}_{3}$-induced $\mathrm{QO}_{2}$ may be also contributed by energy expenditure due to (i) higher active cation transport or from futile cycles coupled to increased catabolism and anabolism, (ii) higher activity of membrane-bound respiratory enzymes due to altered lipid composition of mitochondrial membranes, and (iii) $\mathrm{O}_{2}$ utilization in oxidative stress induced by thyroid hormone calorigenesis (Soboll, 1993; Videla, 2000).

\section{OXIDATIVE STRESS INDUCED BY THYROID} HORMONE

In the liver, $\mathrm{T}_{3}$-induced acceleration of $\mathrm{QO}_{2}$ leads to elevation in superoxide radical and hydrogen peroxide generation at mitochondrial, microsomal, or cytosolic subcellular sites, as well as nitric oxide by nitric oxide synthase. $\mathrm{T}_{3}$ also leads to hyperplasia and hypertrophy of Kupffer cells, with the resulting enhancement in the respiratory burst activity (Videla, 2000). This $\mathrm{T}_{3}$-induced free radical activity diminishes the antioxidant defenses leading to oxidative stress (Fernández \& Videla, 1996), a condition that may lead to a variety of responses depending on the cell type, the level of pro-oxidants achieved, and the duration of the exposure. ROS and RNS species occur at low levels under normal conditions, however, persistent production of large amounts of them may induce significant oxidation of biomolecules, persistent changes in gene expression and signal transduction, thus leading to cell death (Dröge, 2002; Martindale \& Holbrook, 2002). Contrarily, transient fluctuations in ROS and RNS levels may elicit regulation of protein function through reversible oxidation and/or nitrosation of protein sulfhydryls (Klatt \& Lamas, 2000). In addition, regulation of gene expression is also achieved, through modulation of the activity of kinases, phosphatases, and redox-sensitive transcription factors (Thannickal \& Fanburg, 2000; Poli et al., 2004).

\section{REDOX REGULATION OF GENE EXPRESSION BY} THYROID HORMONE

$\mathrm{T}_{3}$-induced calorigenic effect, which becomes significant at 10-12 h after hormone administration, coincides with increases in liver $\mathrm{QO}_{2}$ and in the serum levels of tumor necrosis factor- $\alpha$ (TNF- $\alpha$ ) (Fernández et al., 2002). The latter response is maintained up to $22 \mathrm{~h}$ and is determined by actions exerted at the Kupffer cell level and these are related to the oxidative stress status achieved, as it is abolished by pretreatment with (i) the Kupffer-cell inactivator gadolinium chloride $\left(\mathrm{GdCl}_{3}\right)$, (ii) the antioxidants $\alpha$-tocopherol and $\mathrm{N}$ acetylcysteine (NAC), and (iii) an antisense oligonucleotide targeting the primary RNA transcript of TNF- $\alpha$, prior to hormone administration (Fernández et al., 2002). These pretreatments also markedly reduced liver glutathione (GSH) depletion and the enhancement in biliary glutathione disulfide efflux by $\mathrm{T}_{3}$, supporting the involvement of oxidative stress in the effects elicited by $\mathrm{TH}$ (Fernández et al., 2002). $\mathrm{T}_{3}$-induced TNF- $\alpha$ response is paralleled by activation of 
hepatic nuclear factor $-\kappa \mathrm{B}(\mathrm{NF}-\kappa \mathrm{B})$, as assessed by electrophoretic mobility shift assay, which is suppressed by $\alpha$-tocopherol, $\mathrm{N}$-acetylcysteine, and $\mathrm{GdCl}_{3}$ (Tapia et al., 2003). In agreement with the crucial role of $\mathrm{NF}-\kappa \mathrm{B}$ in controlling the transcriptional activation of cytokine-encoding genes (Tsukamoto, 2002; Dröge 2002), livers from hyperthyroid animals with enhanced NF- $\kappa$ B DNA binding show induced mRNA expression of TNF- $\alpha$ and interleukin (IL)10 , which correlates with increases in the serum levels of the cytokines (Tapia et al., 2003). Upregulation of the IL- $1 \alpha$ gene also occurred after $\mathrm{T}_{3}$ administration, a response that may be due to TNF- $\alpha$ induction (Tapia et al., 2003). The latter changes could play a role in the onset of $\mathrm{TH}$ calorigenesis, as TNF- $\alpha$ and IL- $1 \alpha$ are considered endogenous pyrogens due to their direct effects on the hypothalamus, leading to activation of responses that decrease heat loss and increase heat production (Dinarello, 1999).

TNF- $\alpha$ released from Kupffer cells exhibits autocrine and paracrine actions in the liver through interactions with two surface receptors in target cells, TNF- $\alpha$ receptor 1 (TNFR-1) and TNFR-2, in order to mediate TNF- $\alpha$-dependent signals from cell membrane to nucleus (Garg \& Aggarwal, 2002; Tsukamoto, 2002). Signal cascades operating after TNF- $\alpha$-TNFR-1 coupling are important in the homeostatic response of the liver to oxidative stress. These cascades trigger defense and reparative processes against injury under conditions of moderate pro-oxidant status and low levels of transient TNF- $\alpha$ expression (Garg \& Aggarwal, 2002). Daily $\mathrm{T}_{3}$ administration for three consecutive days resulted in a progressive increase in the oxidative stress status of the liver, with maximal increases in lipid peroxidation and protein carbonylation at $72 \mathrm{~h}$ after hormone treatment (Fernández et al., 2005a). Under these conditions, the serum levels of TNF- $\alpha$ are also enhanced, concomitantly with higher liver inhibitor of $\kappa \mathrm{B}-\alpha \quad(\mathrm{I} \kappa \mathrm{B}-\alpha)$ serine 32 phosphorylation, NF- $\mathrm{KB}$ DNA binding, and the mRNA expression of the NF- $\mathrm{KB}$ responsive genes encoding inducible NOS
(iNOS) (Fernández et al., 2005a), manganese superoxide dismutase (MnSOD), and Bcl-2 (Fernández et al., 2005b). The latter changes and the increase in the hepatic activity of NOS and MnSOD induced by $\mathrm{T}_{3}$ are abrogated by the administration of $\alpha$-tocopherol prior to $\mathrm{T}_{3}$ (Fernández et al., 2005a; 2005b). This is in agreement with the normalization or diminution of oxidative stress-related parameters induced by hyperthyroid state in response to $\alpha$-tocopherol (Asayama et al., 1989; Fernández et al., 2002), NAC (Fernández et al., 2002), or ascorbic acid (Seven et al., 1998), as well as antithyroid therapy alone (Videla et al., 1988; Adali et al., 1999) or combined with $\alpha$-tocopherol (Adali et al., 1999). Suppression of $\mathrm{T}_{3^{-}}$ induced gene expression by $\alpha$-tocopherol and NAC, antioxidants having different mechanisms of action, strengthens the contention that the underlying mechanisms are oxidant dependent (Macdonald et al., 2003). In this context, non-antioxidant ligand-induced effects on specific proteins have been proposed to mediate cell signaling and regulation of gene expression by $\alpha$-tocopherol (Azzi et al., 2004). However, the latter non-antioxidant mechanism is not imitated by structurally related ( $\gamma$-tocopherol) or unrelated (NAC) antioxidants (Azzi et al., 2004) and its relationship with the redox activation of signaling cascades has not been established. Finally, the finding that the mRNA expression of two target proteins of TH action, namely, mitochondrial glycerol-3-phosphate dehydrogenase and the adenine nucleotide translocator 2 , is not modified by $\alpha$-tocopherol and NAC (Videla et al., 2007), suggests that redox regulation of gene transcription by $\mathrm{T}_{3}$ is a secondary mechanism to those triggered by genomic pathways (Fig. 1).

\section{CONCLUDING REMARKS}

Recent data suggest that $\mathrm{T}_{3}$ elicits the redox upregulation of gene expression as a secondary mechanism of ROS produced by $\mathrm{TH}$ calorigenesis, which is triggered by redox-independent (i) direct $\mathrm{T}_{3}$-liganded 
TR interactions with TRE in DNA and/or (ii) indirect induction processes. Upregulation of cytokine-encoding genes in Kupffer cells leads to a $\mathrm{T}_{3}$-induced $\mathrm{TNF}-\alpha$ response, with concomitant IKB- $\alpha$ phosphorylation suggesting the activation of the IкB kinase complex, although the participation of other signaling kinases cannot be discarded.

Upregulation of hepatic iNOS, MnSOD, and $\mathrm{Bcl}-2$ expression by $\mathrm{T}_{3}$ may represent a defense mechanism by protecting the liver from cytokine-mediated lethality and ROS/ RNS toxicity (Dröge, 2002; Martindale \& Holbrook, 2002), which can be accomplished through different actions. First, high levels of NO that are expected upon iNOS expression may limit the redox activation of $\mathrm{NF}-\kappa \mathrm{B}$ through $\mathrm{O}_{2}{ }^{\cdot-}$ scavenging, NF- $\kappa \mathrm{B}$ p50 nitrosylation, and/ or $\mathrm{I} \kappa \mathrm{B}$ induction and stabilization (Laroux et al., 2000). Second, upregulation of MnSOD will increase $\mathrm{O}_{2}{ }^{\bullet-}$ removal, whose production is increased by $\mathrm{T}_{3}$ in mitochondria (Fernández \& Videla 1993a; Venditti et al., 2003), microsomes (Fernández et al., 1985; 2003), and cytosol (Huh et al., 1998). Third, upregulation of hepatic Bcl-2 would diminish apoptosis commitment and increase the antioxidant potential of the liver due to a higher intracellular availability of GSH (Voehringer \& Meyn, 2000). In addition, antioxidant defense mechanisms may involve the upregulation of the $\mathrm{T}_{3}$ responsive nuclear genes for UCP, considering that (i) mild uncoupling by UCP decreases the mitochondrial membrane potential below a critical level, thus increasing $\mathrm{QO}_{2}$ and reducing $\mathrm{O}_{2}{ }^{\bullet-}$ $\mathrm{H}_{2} \mathrm{O}_{2}$ generation (Lanni et al., 2003) and (ii) UCP induction may transport peroxidized unsaturated fatty acid anions, in addition to native fatty acid anions, from the inner to outer side of the inner mitochondrial membrane (Goglia \& Skulachev, 2003), with the consequent diminution in the oxidative damage to mitochondrial proteins and DNA (Lanni et al., 2003; Goglia \& Skulachev, 2003). These observations, and the finding that the CREB binding protein and the related protein p300 activating liganded TR can function as coactivator for various transcription factors including NF- $\kappa \mathrm{B}$ (Yen, 2001), suggest the integration of different $\mathrm{T}_{3}$-signaling inputs to achieve metabolic and redox balance under $\mathrm{TH}$ calorigenic conditions. Recent evidence has suggested alternate nongenomic mechanisms of $\mathrm{TH}$ action involving cell surface $G$ proteincoupled TH membrane-bound binding sites and the activation of signal transducing kinases (Davis et al., 2002). This nongenomic pathway was recently shown to enhance $\mathrm{O}_{2}{ }^{\circ}$ generation and myeloperoxidase activity in rat and human neutrophils, either after addition of 3,5diiodothyronine, $\mathrm{T}_{3}$, and $\mathrm{T}_{4}$ in vitro (Mezosi et al., 2005) or following $\mathrm{T}_{3}$ administration in vivo (Videla et al., 1993; Fernández \& Videla, 1995), which may be of importance as a cellular defense mechanism (Mezosi et al., 2005). Considering that oxidative stress activates numerous important signaling cascades by regulating the function of a variety of enzymes and transcription factors determining transcriptional activation, the influence of $\mathrm{TH}$ on these regulatory processes merits further investigation to understand the complexities of $\mathrm{TH}$ action and the outcome of thyroid gland dysfunction. Of particular importance is the role that $\mathrm{T}_{3}$ administration may have in liver preconditioning, based on the redox upregulation of hepatic proteins involved in cell survival achieved (Fig. 1) (Fernández et al., 2005a; 2005b) and the actions of $\mathrm{T}_{3}$ as a primary hepatic mitogen (Malik et al., 2003), mechanisms that may increase the tolerance of the liver to a subsequent injury (Romanque et al., 2005). This novel hepatic preconditioning strategy is currently under study in our laboratory using the ischemiareperfusion liver injury, a model that is relevant to temporary clamping of the hepatoduodenal ligament during liver surgery and graft failure after liver transplantation in man (Romanque et al., 2005).

ACKNOWLEDGEMENTS

Supported by grant 1050131 from FONDECYT (Chile). 


\section{REFERENCES}

ADALI M, INAL-ERDEN M, AKALIN A, EFE B (1999) Effects of propylthiouracil, propranolol, and vitamin $\mathrm{E}$ on lipid peroxidation and antioxidant status in hyperthyroid patients. Clin Biochem 32: 363-367

ASAYAMA K, DOBASHI K, HAYASHIBE H, KATO K (1989) Vitamin $\mathrm{E}$ protects against thyroxine-induced acceleration of lipid peroxidation in cardiac and skeletal muscles in rats. J Nutr Sci Vitaminol 35: 407 418

AZZI A, GYSIN R, KEMPNÁ P, MUNTEANU A, NEGIS Y, VILLACORTA L, VISARIUS T, ZINGG JM (2004) Vitamin $\mathrm{E}$ mediates cell signaling and regulation of gene expression. Ann New York Acad Sci 1031: 86-95

DAVIS PJ, TILLMANN HC, DAVIS FB, WEHLING M (2002) Comparison of the mechanisms of nongenomic actions of thyroid hormone and steroid hormones. J Endocrinol Invest 25: 377-388

DINARELLO CA (1999) Cytokines as endogenous pyrogens. J Infect Dis 179: S294-S304

DRÖGE W (2002) Free radicals in the physiological control of cell function. Physiol Rev 82: 47-95

FERNÁNDEZ V, BARRIENTOS X, KIPREOS $\mathrm{K}$, VALENZUELA A, VIDELA LA (1985) Superoxide radical generation, NADPH oxidase activity, and cytochrome P450 content in an experimental hyperthyroid state: relation to lipid peroxidation. Endocrinology 117: 496-501

FERNÁNDEZ V, VIDELA LA (1993a) Influence of hyperthyroidism on superoxide radical and hydrogen peroxide production by rat liver submitochondrial particles. Free Rad Res Commun 18: 329-335

FERNÁNDEZ V, VIDELA LA (1993b) 3,3,5Triiodothyronine-induced hepatic respiration: effects of desferrioxamine and allopurinol in the isolated perfused rat liver. Toxicol Lett 69: 205-210

FERNÁNDEZ V, VIDELA LA (1995) On the mechanism of thyroid hormone-induced respiratory burst activity in rat polymorphonuclear leukocytes. Free Radic Biol Med 19: 359-363

FERNÁNDEZ V, VIDELA LA (1996) Biochemical aspects of cellular antioxidant systems. Biol Res 29: 177-182

FERNÁNDEZ V, CORNEJO P, TAPIA G, VIDELA LA (1997) Influence of hyperthyroidism on the activity of liver nitric oxide synthase in the rat. Nitric Oxide Biol Chem 1: 463-468

FERNÁNDEZ V, VIDELA LA, TAPIA G, ISRAEL Y (2002) Increases in tumor necrosis factor- $\alpha$ in response to thyroid hormone-induced liver oxidative stress in the rat. Free Rad Res 36: 719-725

FERNÁNDEZ V, MASSA L, QUIÑONES L, SIMONGIAVAROTTI KA, GIAVAROTTI L, D'ALMEIDA $\mathrm{V}$, AZZALIS LA, JUNQUEIRA VBC, VIDELA LA (2003) Effects of $\gamma$-hexachlorocyclohexane and L3,3,5-triiodothyronine on rat liver cytochrome P4502E1-dependent activity and content in relation to microsomal superoxide radical generation. Biol Res 36: 369-365

FERNÁNDEZ V, TAPIA G, VARELA P, VIDELA LA (2005a) Redox regulation of thyroid hormone-induced Kupffer cell-dependent I $\mathrm{\kappa} \mathrm{B}-\alpha$ phosphorylation in relation to inducible nitric oxide synthase expression. Free Rad Res 39: 411-418

FERNÁNDEZ V, TAPIA G, VARELA P, CASTILLO I, MORA C, MOYA F, ORELLANA M, VIDELA LA (2005b) Redox up-regulated expression of rat liver manganese superoxide dismutase and $\mathrm{Bcl}-2$ by thyroid hormone is associated with inhibitor of $\mathrm{kB}-\alpha$ phosphorylation and nuclear factor-kB activation. J Endocrinol 186: 539-547

GARG AK, AGGARWAL BB (2002) Reactive oxygen intermediates in TNF signaling. Mol Immunol 39: 509517

GOGLIA F, SKULACHEV VP (2003) A function for novel uncoupling proteins: antioxidant defense of mitochondrial matrix by translocating fatty acid peroxides from inner to outer membrane leaflet. FASEB J 17: 1585-1591

HUH K, KWON TH, KIM JS, PARK JM (1998) Role of hepatic xanthine oxidase in thyroid dysfunction: Effect of thyroid hormones in oxidative stress in rat liver. Arch Pharmacol Res 21: 236-240

KLATT P, LAMAS S (2000) Regulation of protein function by S-glutathiolation in response to oxidative and nitrosative stress. Eur J Biochem 267: 4928-4944

LANNI A, MORENO M, LOMBARDI A, GOGLIA F (2003) Thyroid hormone and uncoupling proteins. FEBS Lett 543: 5-10

LAROUX FS, LEFER DJ, KAWACHI S, SCALIA R, COCKRELL AS, GRAY L, van der HEYDE $H$, HOFFMAN JM, GRISHAM MB (2000) Role of nitric oxide in the regulation of acute and chronic inflammation. Antioxid Redox Signal 2: 391-396

MACDONALD J, GALLEY HF, WEBSTER NR (2003) Oxidative stress and gene expression in sepsis. Brit $\mathrm{J}$ Anaeshtesiol 90: 221-232

MALIK R, MELLOR N, SELDEN C, HODGSON H (2003) Triiodothyronine enhances the regenerative capacity of the liver following partial hepatectomy. Hepatology 37 : 79-86

MARTINDALE JL, HOLBROOK NJ (2002) Cellular responses to oxidative stress: signaling for suicide and survival. J Cell Physiol 192: 1-15

MEZOSI E, SZABO J, NAGY EV, BORBELY A, VARGA E, PARAGH G, VARGA Z (2005) Nongenomic effect of thyroid hormone on free-radical production in human polymorphonuclear leukocytes. J Endocrinol 185: $121-129$

MORENO M, LOMBARDI A, BENEDUCE L, SILVESTRI E, PINNA G, GOGLIA F, LANNI A (2002) Are the effects of T3 on resting metabolic rate in euthyroid rats entirely caused by T3 itself? Endocrinology 143: 504-510

POLI G, LEONARDUZZI G, BIASI F, CHIARPOTTO E (2004) Oxidative stress and cell signaling. Curr Med Chem 11:1163-1182

ROMANQUE P, URIBE M, VIDELA LA (2005) Molecular mechanisms in liver ischemic-reperfusion injury and ischemic preconditioning. Rev Méd Chile 133: 469-476

SEVEN A, TASAN E, INCI F, HATEMI H, BURCAK G (1998) Biochemical evaluation of oxidative stress in propylthiouracil treated hyperthyroid patients. Effects of vitamin C supplementation. Clin Chem Lab Med 36: $767-770$

SOBOLL S (1993) Thyroid hormone action on mitochondrial energy transfer. Biochim Biophys Acta 1144: $1-16$

TAPIA G, FERNÁNDEZ V, VARELA P, CORNEJO P, GUERRERO J, VIDELA LA (2003) Thyroid hormoneinduced oxidative stress triggers nuclear factor-kB activation and cytokine gene expression in rat liver. Free Rad Biol Med 35: 257-265

THANNICKAL VJ, FANBURG BL (2000) Reactive oxygen species in cell signaling. Am J Physiol Lung Cell Mol Physiol 279: L1005-L1028

TSUKAMOTO H (2002) Redox regulation of cytokine expression in Kupffer cells. Antioxid Redox Signal 4 $741-748$ 
VENDITTI P, DE ROSA R, DI MEO S (2003) Effect of thyroid state on $\mathrm{H}_{2} \mathrm{O}_{2}$ production by rat liver mitochondria. Mol Cell Endocrinol 205: 185-192

VIDELA LA, SIR T, WOLFF C (1988) Increased lipid peroxidation in hyperthyroid patients: suppression by propylthiouracil treatment. Free Rad Res Commun 5: 1-10

VIDELA LA, CORREA L, RIVERA M, SIR T (1993) Zymosan-induced luminol-amplified chemiluminescence of whole blood phagocytes in experimental and human hyperthyroidism. Free Radic Biol Med 14: 669-675

VIDELA, LA (2000) Energy metabolism, thyroid calorigenesis, and oxidative stress: functional and cytotoxic consequences. Redox Rep 5: 265-275
VIDELA LA, FERNÁNDEZ V, TAPIA G, VARELA P (2007) Thyroid hormone calorigenesis and mitochondrial redox signaling: upregulation of gene expression. Front Biosci, 112: 1220-1228

VOEHRINGER DW, MEYN RE (2000) Redox aspects of Bcl-2 function. Antioxid Redox Signal 2: 537-550

WEITZEL JM, RADTKE C, SEITZ HJ (2001) Two thyroid hormone-mediated gene expression patterns in vivo identified by cDNA expression arrays in rat. Nucleic Acids Res 29: 5148-5155

YEN PM (2001) Physiological and molecular basis of thyroid hormone action. Physiol Rev 81: 1097-1142 
